\title{
The Vital Role of Pink Marketing in the Creation of Women Loyalty
}

\author{
Aram Hanna Massoudi ${ }^{1}$ \\ ${ }^{1}$ Department of Business Administration, Cihan University-Erbil, Iraq
}

\section{ABSTRACT}

Keywords: Loyalty, Pink Marketing, Pink Marketing Mix, Maybelline New York.
Purpose of the study: This study stresses the vital role of pink marketing in the creation of women loyalty. The study revolves around the fundamental question: Does the pink marketing mix of Maybelline New York beauty products have any critical effect on women's loyalty in the Kurdistan Region?

Methodology: The article applies an analytical-descriptive approach. The data were composed by a questionnaire circulated to 125 women consumers at local shopping malls in Erbil province, Iraq. Statistical tools were used to test and analyze the data using SPSS software. including: descriptive statistics to provide a comprehensive description of the sample in terms of demographics. Arithmetic mean and standard deviations to judge the response of sample items to study variables, Cronbach Alpha to ensure the validity of the study, and Pearson correlation coefficient test to recognize the nature of the relationship between the variables studied.

Main Findings: The result showed that pink marketing mix does have a positive relationship with loyalty. Pink product, Pink price, Pink promotion, and place all have modest to weak correlation with loyalty.

Research limitations/implications: This article focused on small group of women shoppers and one brand of cosmetics in its survey thus, the findings can't be comprehensive to cover the whole region due to the restrict movement because of COVID 19 outbreak in the region.

Novelty/Originality of this study: The findings of the study donates to a full comprehension of viable pink marketing mix for achieving women shoppers' loyalty precisely in the cosmetics and beauty supplies industry and propose a direction to marketers on how to move women shoppers to be loyal.

\section{INTRODUCTION}

With congested modern concepts and terminologies at present time, especially in the areas of marketing, several types of researches have emerged in different fields. And because women are the basis of society and counted as half of it, a new type of marketing has emerged. Marketing that is oriented towards women called pink marketing, and the origin of this label goes back to the distinctive color of women, which is pink. Pink marketing is a recent trend, and many businesses have started especially in developed countries, to adopt and implement this concept (Rohrer-Vanzo et al., 2016). Women occupy many areas of life; therefore, they were the focus of many organizations by developing and improving marketing strategies towards women groups (Barletta, 2003). Women do have a vital role in our communities especially in purchasing decisions; this role stems from women's success in many tasks as a consumer and a decision-maker, as well as an influential role in the purchasing decision-making process of other people (Massoudi, Jameel, \& Ahmad, 2020). Alternatively, institutions today are paying great attention to customers, and establishing interactive relationships with them to gain trust and loyalty. Also, by providing information customers need before acquiring goods and services. Therefore, understanding the customer desire and needs lead to loyalty.

The participation of women in the marketing process, whether existing or targeted, makes us think of the role and relationship of women to marketing activity and its objectives, especially the satisfaction of customers and loyalty (Gazi, 2019). Women can perform the marketing function and affected differently from men. This fact which is described in the book writers lead us to know the fact that women privacy must be taken into account to reach marketing objectives, especially customer loyalty. The problem of the study revolves around the following fundamental question: How does the pink marketing of Maybelline New York beauty products affect women's loyalty in the Kurdistan Region?

The article objectives are: To recognize the impact of pink marketing of Maybelline New York beauty products on customer loyalty in Kurdistan, particularly the pink marketing mix elements. Also, to highlight the importance of pink marketing for women in Kurdistan, especially in Kurdish society in general; and to attempt to change the traditional view of women by marketers, and consider it an essential party in the marketing process, because of their creative and different intellectual skills, especially in the field of marketing goods and services for women. Finally, trying to provide suggestions to Kurdish 
institutions on the importance of allocating a marketing mix for women. Motivate and encourage other researchers in the field of marketing to study and deepen their knowledge in this new field, which is pink marketing (Abubakar \& Obansa, 2020).

\section{LITERATURE REVIEW}

\subsection{Pink Marketing: Women as a Consumers}

Women signify more than half of the global population. Directly or indirectly, consumer spending by women account for almost $85 \%$ of world purchases counting automobiles to healthcare (Rohrer-Vanzo et al., 2016; Barletta, 2003). Women considered the chief players in economics, and other action of the life (Sutter et al., 2016). Women gained more independence from men, due to professional success and economic autonomy: These factors impacted women behavior in purchasing goods. A result of that, there is minimal differences between female and male targets, in purchasing. On the other hand, males are prouder with the detail care as look, pleasure and moral needs. On the other side, nowadays women are competing with traditional male categories like automotive, high tech and financial services. In fact, in the past, a particular women's dissatisfaction through the commercial, insurance and automotive offer was evident: this because these services were not appropriate for their necessities. Despite these recent changes, women remain as the principal gender that put at the first-place products and services' quality or value. Recent studies verified that the price isn't the most crucial driver for the purchasing decision. Still, women prefer products and service, basing their preferences on the contrast between what they "get" and "give". Indeed, in the last few years, a new economic process is involving a significant number of female consumers.

Product's color the you direct to the shopper base can have a substantial influence on accomplishing your business goals. Emotionally, the color pink is linked with empathy, love, and passion. The color pink is womanly, soft and youthful. Also, it represents love and compassion.

\subsubsection{Definition of Pink Marketing}

According to Abdul Fatah, (2017), the term pink marketing has been used to refer to targeted marketing for women, the pink color is undoubtedly the color of femininity, and this is what made marketing scientists and experts use it as an indication of marketing directed towards women. On the other hand, products directed to women can be colored pink or any different color that suits the female $(\underline{Y}$ ano,2013). This varies according to the nature of the product and according to the needs and desires that the foundation intends to achieve the female through its product. Some believe that the term pink marketing is limited to women's sales. Some define it as: How do you market for women? And, it is true that women's marketing in those selling efforts implemented to know women, or targeted to female clients, or by defining other marketing to and from women.

Pink marketing or marketing to women is a marketing strategy based on targeting women in the institution's products where the institution uses the marketing techniques that is more influential in women than in men, because the psychological nature of women differs from the subjective view of men. This means that the motives for buying among women are different from the purpose of buying in men. Therefore, the purchasing behavior of women differs from the purchasing behavior of men. Female marketing or as known in foreign literary writing as pink marketing does not target women as a customer or buyer only but also address the role of women in serving the marketing areas in general, whether they serve clients from young girls or that use plans and marketing issues for the market as a whole.

Pink marketing can be defined as applying the elements of a product marketing mix, pricing, promotion, and distribution in a manner consistent with and commensurate with the psychological and lifestyle of women, to encounter their needs and desires in an excellent way that enables to reach the stage of loyalty (Kaddumi, 2017).

Pink Marketing is also known as all activities and marketing efforts targeted at women clients from product, price, distribution and promotion in a way that suits women. Organizations equivocally address women with its marketing messages, because this approach is characterized by a pattern that no longer applies to women, so marketing messages are required to show understanding and conformity with the essence and needs of the women (Ahmed, 2017). Pink Marketing is the marketing effort that seeks to fulfil the needs and desires of women of goods and services by collecting marketing information commensurate with their trends and tastes (Alubaidi, 2016).

It is noted that pink marketing not only sell products to women, but extends to products. It is aimed at men, as the woman affect the man's decision. That is, companies must target women marketing campaigns, as they influence the decision-making of the buyer, and this requires the use of marketing expertise in marketing campaigns for products intended for men, for children, or the family. It gives signals or suggestions that affect the woman and convince her to buy these products.

\subsubsection{The Importance of Pink Marketing}

According to Pashley (2016), pink marketing is essential through the following reasons:

1. The importance of a woman in the marketing field stems from several aspects, and not just because she is a buyer and seller. Women are involved with their household decision-making and in their professional career. Also, women possess a large share of the world wealth.

2. Women's purchases represent $85 \%$ of all purchases in the world, starting from personal care products, health supplies to cars and equipment.

3. Women's expenses represent $58 \%$ of all payments online.

4. Women's expenditures in the world represent about $\$ 20$ trillion annually.

5. The women buy about $58 \%$ of the cars in the American market, and its impact extends to $80 \%$ of the beauty supply market. 
6. The status of the woman and her care ingrained the Arabic culture in particular and the Eastern culture in general.

7. The Arab region maintains a large share of world wealth. Therefore, the percentage of what belongs to a woman has up to about $40 \%$ of the wealth. This is a strong indicator of the role of the women in the Arab economy.

8. Women represent a considerable segment of clients and consumers in all markets where the duty of appreciation must be taken into consideration (Pashley, 2016).

Marketing to women reveals the essential ideas for success in marketing products and services in the woman's market growing and developing when institutions understand and meet the needs of women, they can succeed in developing and increasing market shares (Berletta, 2003).

\subsubsection{Requirements for Successful Pink Marketing}

Abdul Fatah, (2017) stated following points as among the requirements for successful pink marketing

1. Firms should focus on emotional temptations rather than on logical attraction in advertising and in persuasion women are presented by sale representative, so a passionate woman is better to persuade by influencing her emotions, and the effect on emotions does not mean cheating or neglecting the logical aspects of the product such as quality and price. Still, it means focusing more on emotional issues.

2. Firms must provide additional services and excellent customer service. Studies showed that $65 \%$ of female's customers have loyalty to a certain brand at first positive experience with the brand. This indicates the importance of offering good customer service for women, because you can win them as customers by just positively dealing with them at the first encounter.

3. Targeting women with more social media marketing campaigns, as females spend a bit more time $40 \%$ on social media than their men counterparts.

4. Use appropriate colors for women in products and advertisements, such as the use of pink or red and stay away from colors that suit males like blue.

5. In women advertising, firms should work to influence their subconscious more than ever, including the use of clear phrases that affect consciousness such as "because you are a female", or "this product is for you". But rather it is best to influence the subconscious through the advertisement background, such as the references that indicate femininity, such as music and colors, used in the advertisement, or the presence of flowers and roses in the advertisement (Abdul Fatah, 2017, PP. 21-22).

In order to reach a successful pink marketing, the essential elements must be taken into consideration that women rely on them to make their decisions. These elements can be illustrated in figure 1 below:

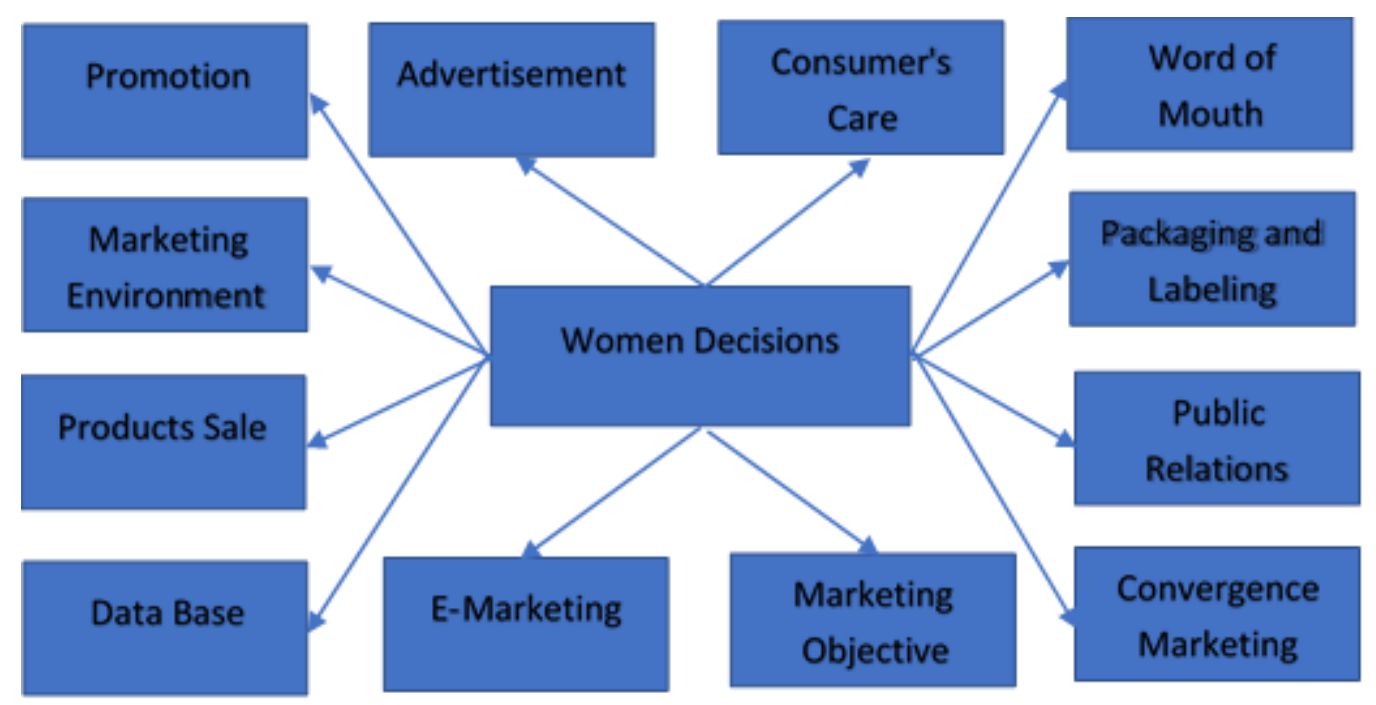

Figure 1: Elements of Women Buying Decision

Source: Berletta, 2013, P. 67

We notice from Figure No. (1) that the woman's decisions are taken and influenced by the observance of various elements and factors, including the spoken word, public relations and consumer care so that the products and services directed to the woman must take into account these elements because it is important for woman, when the institution identifies these factors, especially, the most influential ones, it can guide them and make them the starting point through which it creates the desire to buy for women.

\subsection{Marketing Mix and Pink Marketing Applications}


Pink marketing is a modern terminology in marketing as it began at the beginning of the 21st century, where many institutions in the world tend to adopt a pink marketing strategy and apply it to women by molding the four elements of marketing mix (product, pricing, promotion and distribution), in a manner consistent with the dimensions of the woman's life.

\subsubsection{Pink Product}

We can clarify the pink product as a representation of any good or service produced and compatible with women desires, and needs and tastes of women customers. It is worthy to note here that women shoppers look for information and details about a certain brand and pay more attention to specification more than men. Women dissect every piece of information about the product. For example, when a woman purchases clothes, she cares about the quality of clothes, their compatibility with fashion, and the appropriate range. These clothes are for their appearance, as they are concerned with the number of pieces offered of the same variety, they are looking for excellence in clothing more than men since mothers are interested in reading the components of food products that they buy for their children, and they are very keen for their children, and do not buy any product for their children before making sure it is health for them. Therefore, when institutions provide their products directed towards women, they must take care of all the details. Also, sales officials must provide all information about the products when the women make purchase (Alubaidi, 2016, P.406).

\subsubsection{Pink Price}

It represents the amount that women customers pay for the product without exploiting their weaknesses. In general, the product that a man sees as a high-priced product may be seen by the woman as cheap, because that meets the moral needs that a man may not see in this product, as well as the man may not pay much attention to product packaging and the accessories attached to the product, but for the woman, she may care more about these details, and the money women spend on is often greater than the money spent by man. Sometimes a business firm targets women and clients from specific age groups and social classes, such as targeting the upper and middle class of society to purchase the product, and this enables the organization to establish a pricing strategy based on the perceived value of the product.

\subsubsection{Pink Distribution (Place)}

It represents the site where the product is sold to women customers with the need to take into account their tastes in the colors and the forms used in its external and internal designs. The man focuses more on the physical elements in the stores, as he is interested in having a parking lot in order to park his car and focus on the stock in the store, while the woman emphases on the packaging, décor, attentive customer service, and treatment of the sales people (Alubaidi, 2017, P.407).

In order for the organization to guarantee an efficient distribution of its products, it must use an extensive network characterized by strong distribution in order for this network to reach consumers effectively and efficiently. Firms are able to accomplish this by making the products available in the stock and by creating an affordable pricing strategy in stores, supermarkets and shopping malls.

\subsubsection{Pink Promotion}

It represents the way to communicate with female clients without exploiting their innate tendencies and weaknesses, as well it must be noted that a woman is more emotional than a man, as she cares more about emotions than logical information. A woman can be convinced of the product through her emotions, while a man is convinced of the product through the mental trial of the product. This does not mean that the woman does not care about logical matters; but is more concerned with the emotional aspects. Therefore, institutions that direct their products towards women must concentrate on expressive attractions in their advertising operations and present common-sense information about the products. Aluubaidi (2017) explains what women like in the advertising campaign including the attention to emotion, harmony, and colors. For example, maternity products intended at mothers must emphasize on the motherhood feeling and their sensitivity toward their babies.

Also, promotion can be highlighted by unique forums of products; advertising and promotion can be done with the help of print media and publications, this type is traditional, but over time, media has evolved and advertising and promotion of products has become geared towards the experience of the product on the ground, and even access to the most important methods of persuasion and promotion must rely on the spoken word that lists successful experiences of certain products, as $64 \%$ of mothers ask their friends about products before they are purchased, thus, the word of mouth stands out as an important advertising method among women in pink marketing.

\subsection{The Concept of Loyalty}

Most organizations realized that its success and stability depend on its ability to know and define the needs and desires of its customers, and its ability to satisfy them, and as a result of intense competitive reality, the corporations have been forced to strive to satisfy their customers, and that is why loyalty has become an important topic for all small and large business organizations. That is why we will try give a comprehensive view of this topic and the most important concepts related to loyalty.

According to Alnosoor (2014), customer's loyalty is how an organization earns customer's trust where the relationship that governs the exchange process between them are equally profitable. Also, Liu et al. (2017) defined loyalty as customer deals with the same service and commodity for long time. Kotler. (2014) defined loyalty as customer scale and willingness to reciprocate the activities with the organization. Also, Dick \& Basu., (1994) stated that loyalty is also known as the purchase by the customer from the same store (a specific store) permanently or by all or most of his needs from this store, because of the 
positive trend that of the customer towards this store. This is supported also by Massoudi (2020) he stated that loyalty is the consistent identification of consumers with their favorite store. Hanzaee \& Farsani., (2011) indicated that high-level customer loyalty means high market share and the ability to request relatively high prices compared to others' prices; loyal consumers are more likely to buy back the same service or brand, and provide a positive spoken word and are willing to pay a premium price.

Few studies had focused on loyalty, such as Dick \& Basu., (1994) which classified consumer's loyalty into two scopes they are relative attitude and repeat patronage; they grouped these scopes into 4 types of loyalty: spurious loyalty, latent loyalty, loyalty, and no loyalty. This loyalty classification is very essential to marketers and advertisers because of its significant influence and insinuations. The two scopes focused on both reactional and conduct scopes of loyalty (Bowen \& McCain., 2015). The creation of loyal customer is one of the great arsenals firm has against its competition. Dick \& Basu., (1994) notion consumer's loyalty was based on the connection among the customer's relative attitude towards the brand and his repeated patronage behavior. It has been contended that mixing attitude with the loyalty paradigm (patronage behavior) will improve projecting capability (Dick \& Basu, 1994). Precisely, attitudinal loyalty denotes consumer's expressive attachment whereas behavioral loyalty means the actual behavior of the customer. Therefore, when a study conducted about loyalty, it is recommended to apply both attitudinal and behavioral dimensions of loyalty to gain a proper understanding of customer loyalty. One very interesting study was done by Tanford \& Baloglu., (2013) where loyalty was divided into nine groups these nine loyalty are: 1) True loyalty is the combination of high attitudinal loyalty and high behavioral loyalty, 2) Active loyalty is the emotional attachment to a brand or firm, 3) Latent loyalty is a high attitudinal loyalty with no consumer behavior, 4) Projected loyalty is a consumer's high consumption of the brand and increased sense of belonging to the firm, 5) Neutral loyalty is the average levels of attitudinal and behavioral loyalty, 6) basic loyalty which is the consumer's low consumption of the brand but of which may increase, 7) Spurious loyalty is high behavioral loyalty with low attitudinal loyalty, 8) Ultimate loyalty is the average level of behavioral loyalty and low attitudinal loyalty, and finally 9) No loyalty offers nominal customer retention.

Other studies such as Chang et al. (2009) inspected the loyalty from three viewpoints: attitude, behavior, and compound. Casidy \& Wymer., (2016) did hypothesized the notion of loyalty as a client's emotional state towards a certain brand. In addition, Izogo (2016) has counseled authors to gauge the impacts of customer fulfilment, trust, quality, and image in attitudinal loyalty. Finally, the studies by (Dwivedi \& Merrilees., 2016; Thaichon \& Jebarajakirthy 2016; Ali et al. 2016) have measured the intentions customer's loyalty and gauged the attitudinal and behavioral loyalty.

Lastly, it is vital for businesses to recognize the connection between shopper satisfaction and loyalty (Massoudi, 2020). Satisfaction of the customer is a vibrant feature in increasing customer loyalty. Both notions should be combined to gain the anticipated objectives of the firm, its profitability and market share. Satisfaction is a respectable gauge of a customer's repeated purchasing behavior (Woodcock et al., 2003). Dissatisfied customers may damage the name of that firm, and satisfied customers will buy the product, ignore the sensitivity of the price, involve in and encourage word of mouth, and convert to loyal client (Chen and Wang, 2009).

\subsection{Hypothesis}

When it comes to loyalty, the majority of previous studies were related to marketing mix or the relation with customer satisfaction. However, no study did target pink marketing and its role in creating women loyalty. Therefore, in order to answer the problem, we developed the main hypothesis of the study and a set of sub hypotheses to support the main hypothesis.

The main hypothesis: There is a statistically significant positive correlation between pink marketing mix of Maybelline New York cosmetic products and the loyalty of women customers in the Kurdistan Region. The main proposition is divided into the following sub-hypotheses:

H1: There is a statistically significant positive correlation between the pink products of Maybelline New York cosmetics products and achieving women customers' loyalty in the Kurdistan Region.

$\mathrm{H} 2$ : There is a statistically significant positive correlation between the pink pricing of Maybelline New York cosmetics product and achieving women customers' loyalty in the Kurdistan Region.

H3: There is a statistically significant positive correlation between the pink promotion of Maybelline New York cosmetics products and achieving women customer's loyalty in the Kurdistan Region.

H4: There is a statistically significant positive correlation between the pink place of Maybelline New York beauty products and achieving women customer's loyalty in the Kurdistan Region.

\section{METHODOLOGY}

This section will identify the approach of the field study and identify the study sample. The researcher will identify the collection and the analysis of the data to help support the chosen approach. A questionnaire form was utilized for data collection. The form was divided into two variables pink marketing mix with 15 statements and the loyalty variable with five statements. The target group of the questionnaire were a group of women customers trying to purchase Maybelline New York brands in Family Shopping Mall, Erbil Iraq. The researcher has relied on the case study as part of the descriptive analytical approach. This approach is important in this field of study through the collection of data, information, facts and opinions, which would give a clear explanation of the case under study. A total of 130 questionnaires were distributed randomly, 5 were rejected and 125 were valid for the analysis. 
The answer for each statement of the questionnaire was scaled according to the Likert scale Alternatives (strongly disagree with a mean score of less than 1, disagree with a mean score of 1-2, neutral with an average mean score of 2-3, agree with a mean score of 3-4, strongly agree a mean score of over 4). Statistical tools also were used to test and analyze the data using SPSS 22 software: Frequency, percentages to provide a comprehensive description of the sample in terms of demographics including age, education, and employment. Arithmetic mean a measure of central tendency and standard deviations a measure of dispersion. They are also to judge the response of the sample items to study variables. Cronbach Alpha to ensure the validity of the study instrument and its stability. Pearson correlation coefficient test to identify the nature of the association or relationship between the two continuous variables of the study. The research model is illustrated in figure 2 below:

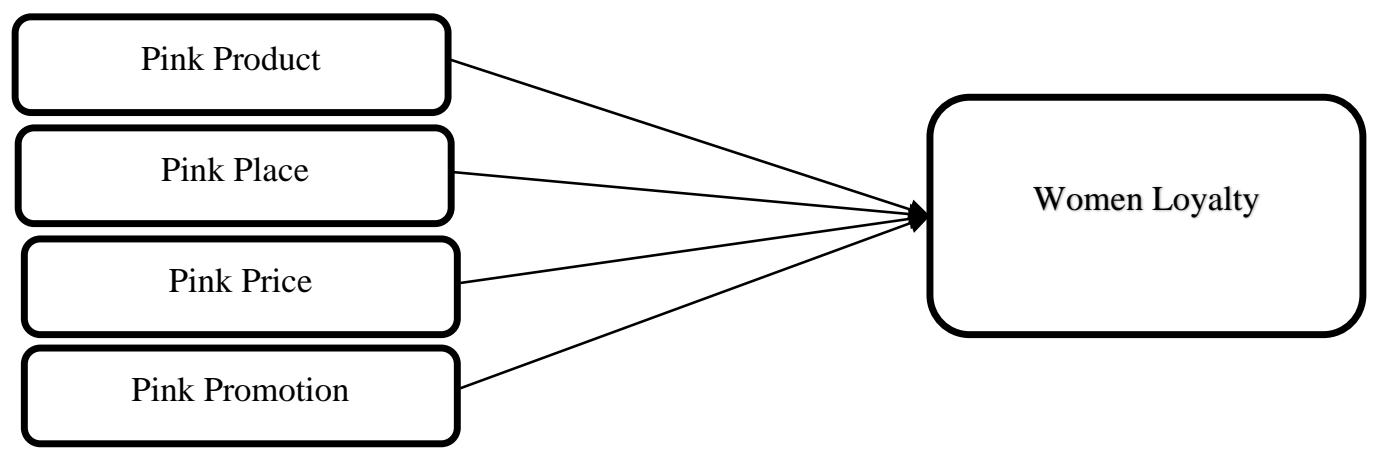

Figure 2: Conceptual Framework

\section{RESULTS / ANALYSIS}

\subsection{Demographics}

Table No. 1

Age

\begin{tabular}{|c|c|c|}
\hline Variable & Frequency & Valid Percent \\
\hline Age & & \\
\hline $18-24$ & 54 & 43.2 \\
\hline $25-30$ & 44 & 35.2 \\
\hline $31-45$ & 25 & 20 \\
\hline Over 45 years & 2 & 1.6 \\
\hline Total & 125 & 100 \\
\hline
\end{tabular}

We can see from table 1 that the majority of our respondents who purchase Maybelline New York are between 18-24 which was $(43.2 \%)$. The second respondents were between the ages of 25-30 (35.2\%). Also, 20\% of respondents aged between 31-45 were customers of Maybelline New York.

Table No. 2

Education

\begin{tabular}{lcc}
\hline \multicolumn{1}{c}{ Variable } & Frequency & Percent \\
\hline 'Education & 1 & 0.8 \\
Elementary School & 5 & 4 \\
High School & 29 & 23.2 \\
Associate & 63 & 50.4 \\
Bachelor & 27 & 21.6 \\
Master & 125 & 100
\end{tabular}

In regard to education, table 2 shows that the majority of Maybelline New York customers were educated, where 63 respondents $(50.4 \%)$ had a bachelor degree. 29 respondents $(23.2 \%)$ had an associate degree, and 27 respondents $(21.6 \%)$ had a master degree. This indicates that educated women have more knowledge about name brands than uneducated women.

Table No.3

Employment

\begin{tabular}{lcc}
\hline \multicolumn{1}{c}{ Variable } & Frequency & Percent \\
'Employment & 76 & 60.8 \\
Employed & 49 & 39.2 \\
Unemployed & 125 & 100 \\
\hline
\end{tabular}

Table 3 showed that the majority of our respondents 76 of them $(60.8 \%)$ were employed and 49 respondents $(39.2 \%)$ were unemployed. 


\subsection{Reliability Test}

The researcher applied Cronbach Alpha to examine the reliability of the questionnaire statement. Reliability usually controlled by Cronbach's alpha, a well-known method for estimating dependability. Pourdehghan., (2015). proposes that for any exploration at, an unwavering quality score or alpha that is 0.60 or above is adequate. In this research, all 125 respondents noted their answers. As appeared in table 4, just components which has great degrees of unwavering quality (more noteworthy than 0.70 ) which all met the threshold requirement suggested by Nunnally are considered below than that were removed. Table 5 shows the reliability test for 15 of the questionnaire 20 statements.

Table No. 4

Case Processing Summary

\begin{tabular}{|l|l|r|r|}
\hline \multicolumn{2}{|c|}{} & $\mathrm{N}$ & \multicolumn{1}{|c|}{$\%$} \\
\hline \multirow{3}{*}{ Cases } & Valid & 125 & 100.0 \\
\cline { 2 - 4 } & Excluded $^{\mathrm{a}}$ & 0 & .0 \\
\cline { 2 - 4 } & Total & 125 & 100.0 \\
\hline
\end{tabular}

Table No. 5

Reliability Statistics

\begin{tabular}{|c|c|c|}
\hline Cronbach's Alpha & $\begin{array}{l}\text { lronbach's Alpha } \\
\text { Based on } \\
\text { Standardized Items }\end{array}$ & No of Items \\
\hline .882 & .891 & 15 \\
\hline
\end{tabular}

Table 5 shows overall reliability statistics 0.882 . It is observed from table no. 5 that all the items have achieved reliability more than .800 .

\subsection{Descriptive statistics}

Descriptive statistics summarize a set of data. It measures of central tendency and of dispersion. Table 5 shows the mean outputs mean and standard deviation scores in addition to the degree of its approval.

Table No. 6

Item Statistics

\begin{tabular}{lccc}
\hline & Mean & Std. Deviation & $\mathrm{N}$ \\
\hline Loyalty & 3.96 & 1.409 & 125 \\
Price & 3.35 & 1.085 & 125 \\
Place & 3.31 & 1.245 & 125 \\
Promotion & 3.38 & 1.215 & 125 \\
Product & 3.68 & 1.156 & 125 \\
\hline
\end{tabular}

We noticed from table no. 6 that the overall degree of approval of the loyalty dimension was high with an average mean of 3.96 and a standard deviation of 1.40 , as the sample respondents highly agreed to loyalty variable.

Also, the overall degree of approval of the pink marketing mix dimensions were high with an average mean of 3.35 and a standard deviation of 1.08 for the price. Also, the overall degree of approval of the pink marketing mix dimension of place was high with an average mean of 3.31 and a standard deviation of 1.24. Also, the overall degree of approval of the pink marketing mix dimension promotion was high with an average mean of 3.38 and a standard deviation of 1.21. Finally, the overall degree of approval of the pink marketing mix dimension product was high also with an average mean of 3.68 and a standard deviation of 1.15 . From the above scores, we can confirm that the sample respondents highly agreed to pink marketing mix variables and loyalty.

\section{DISCUSSION}

Table No.7

Correlation between Pink Marketing and Loyalty

\begin{tabular}{llcc}
\hline & & Loyalty \\
\hline Pink Marketing Mix & Pearson Correlation & 1 & $.817^{* *}$ \\
& Sig. (2-tailed) & 125 & .000 \\
& $\mathrm{~N}$ & & 125 \\
Loyalty & Pearson Correlation & $.817^{* *}$ & 1 \\
& Sig. (2-tailed) & .000 & 125 \\
& $\mathrm{~N}$ & 125 & \\
\hline
\end{tabular}

** .Correlation is significant at the 0.01 level (2-tailed)

Table 7 clearly shows a positive correlation between pink marketing mix and loyalty, where Pearson correlation coefficient value indicates a very strong correlation of $(0.817)$, and significant value is $0.000<0.05$. This indicates that every time the pink marketing increased by one unit, the level of loyalty increases by $81 \%$ and it is a good value. Therefore, the alternative hypothesis is accepted and the null hypothesis is rejected. This leads us to conclude that pink marketing mix has a positive significant relationship on loyalty. 
Table No.8

Correlation between Product and loyalty

\begin{tabular}{llcc}
\hline & & Pink Marketing Mix & \\
& & & \\
\hline Pink Marketing Mix & Pearson Correlation & 1 & $.546^{* *}$ \\
& Sig. (2-tailed) & & .000 \\
Loyalty & $\mathrm{N}$ & 125 & 125 \\
& Pearson Correlation & $.546^{* *}$ & 1 \\
& Sig. (2-tailed) & .000 & 125 \\
\hline
\end{tabular}

**. Correlation is significant at the 0.01 level (2-tailed).

Table 8 shows a modestly positive correlation of $(0.546)$, and significant value is $0.000<0.05$. Indicating that every time the level of product increases by one unit, the loyalty level increases also by 54\%. Thus, hypothesis 1 is accepted.

Table No.9

Correlation between Price and loyalty

\begin{tabular}{llcc}
\hline & & Pink Marketing Mix & Loyalty \\
\hline Pink Marketing Mix & Pearson Correlation & 1 & $.417^{* *}$ \\
& Sig. (2-tailed) & & .000 \\
\multirow{4}{*}{ Loyalty } & N & 125 & 125 \\
& Pearson Correlation & $.417^{* *}$ & 1 \\
& Sig. (2-tailed) & .000 & 125 \\
\hline
\end{tabular}

**. Correlation is significant at the 0.01 level (2-tailed).

Table 9 shows a poor correlation of $(0.417)$, and significant value is $0.000<0.05$. Thus, every time the level of price increases by one unit, the loyalty level increases by $41 \%$ also. Accordingly, we accept hypothesis 2 .

Table No.10

Correlation between Promotion and Loyalty

\begin{tabular}{llcc}
\hline & & Loyalty \\
\hline Pink Marketing Mix & Pearson Correlation & 1 & $.203^{* * *}$ \\
& Sig. (2-tailed) & .000 & 125 \\
& $\mathrm{~N}$ & 125 & 1 \\
Loyalty & Pearson Correlation & & 125 \\
& Sig. (2-tailed) & $.203^{* *}$ & .000 \\
& $\mathrm{~N}$ & 125 & 125
\end{tabular}

**. Correlation is significant at the 0.01 level (2-tailed).

Table 10 shows weak correlation between the pink promotion and loyalty, the Pearson correlation coefficient has poor value of $(0.203)$, and significant value of $0.000<0.05$. Therefore, every time the level of price increases by one unit, the loyalty level increases by $20 \%$ also. Thus, we accept hypothesis 3.

Table No.11

Correlation between Place and loyalty

\begin{tabular}{llcc}
\hline & & Pink Marketing Mix & Loyalty \\
\hline Pink Marketing Mix & Pearson Correlation & 1 & $.393^{* *}$ \\
& Sig. (2-tailed) & & .000 \\
Noyalty & Pearson Correlation & 125 & 125 \\
& Sig. (2-tailed) & $.393 * *$ & 1 \\
& N & .000 & 125 \\
& & & 125
\end{tabular}

**. Correlation is significant at a 0.01 level (2-tailed).

Table 11 also shows weak correlation between the pink place (distribution) and loyalty. The value of Pearson correlation coefficient has poor correlation of $(0.393)$, and significant value is $0.000<0.05$. Thus, every time the level of distribution increases by one unit, the loyalty level increases by $39 \%$ also. Accordingly, we accept hypothesis 4.

This empirical study examined the connection between pink marketing mix and women loyalty. The study sample was a group of women shoppers of Maybelline New York products located in shopping malls in Erbil, Kurdistan Region of Iraq. The study

Please cite this article as: Massoudi, A. H. (2020). The Vital Role of Pink Marketing in the Creation of Women Loyalty. International Journal of Social Sciences and Economic Review, 2(3), 28-37. doi:10.36923/ijsser.v2i3.74 
took an analytical-descriptive approach. The data were analyzed by SPSS. Finally, we tested the main hypothesis and the subhypotheses by using Pearson Correlation. The finding was supported by (Pourdehghan 2015). That marketing mix has positive relation with customer loyalty. From our analysis, we came to conclusions that will be presented in the next chapter.

\section{CONCLUSION}

This article aimed to explore pink marketing mix part in gaining customer loyalty. After reviewing and analyses of the data, the researchers came to the following conclusions: There is a high acceptance for the independent variable (pink marketing) among the research sample. Also, the degree of acceptance for pink product and pink distribution were high also. On the other hand, there was a low acceptance of respondents about the implementation of pink price and pink promotion. A very high acceptance rate for the dependent variable (loyalty) by the study sample. This show that our sample are loyal to Maybelline New York products. Finally, pink product has positive correlation with loyalty. This show quality, product design, and product improvement correlate with customer loyalty. And pink price also has positive correlation with loyalty. This indicates that the suitability of the price with the woman educational level, the suitable price for women, the price is not the first priority for women correlate with customer loyalty. Finally, pink distribution has positive correlation with loyalty. This means that the availability of the product in the right place, right time, and right assortment correlate with customer loyalty. In addition, pink promotion has positive correlation with loyalty. This shows that focusing on women emotion in marketing, not exploiting women in marketing commercials, free trial service correlate with customer loyalty.

\section{LIMITATIONS AND FUTURE RECOMMENDATIONS}

Based on our research results, the researchers came to the following suggestions: Pink promotion plays an essential role in customer loyalty. Therefore, every firm targeting women shoppers should not ignore the promotional side in reaching women trust and loyalty. Also encouraging institutions to promote pink marketing. Also, Maybelline New York should offer promotional offers and services to retailers in Kurdistan Region to increase the communication channels between them and women in the region. Retailers should concentrate more on pink marketing in our society. Finally, the creation of institutions that support pink marketing especially in the health sector. Including institutions related to women protection from cancer such as breast cancer.

Limitations: This article focused on small group of women shoppers and one brand of cosmetics in its survey, thus, the finding cannot be comprehensive to all the entire region due to COVID 19 outbreak in the region.

This research focused on pink marketing mix and its role on customer's loyalty. Other issues such as the role of word of mouth in activating pink marketing and the challenges that prevent institutions in the region from implementing pink marketing are subject for future studies.

\section{REFERENCES:}

Abbas, H. \& Aljanabi, M. (2017). Customer Relation Management. Jordan: Alsaffaa Publication.

Abdul Fatah, H. (2017). Women Marketing. Alexandria, Egypt: Huros International Press.

Abo Qahf, A. (2004). Political Marketing, The Art of Negotiation. Alexandria, Egypt: New University Press.

Abubakar, I., \& Obansa, S. (2020). An Estimate of Average Cost of Hypertension and its catastrophic effect on the people living with hypertension: Patients' perception from two Hospitals in Abuja, Nigeria. International Journal of Social Sciences and Economic Review, 2(2), 10-19.

Ahmed, F. (2017). Study of the Elements that Effect Women Buying Decision. Master Thesis. Sudan University for Science and Technology.

Al-Rubaei, Z. M., Alubaidi, G. H., \& Alubaidi, T. A. (2017). Kinetic Study of the Effect of Some Novel Lipid Lowering Compounds on Activities of Creatine Kinase and 3Hydroxy-3-Methyl-Glutaryl-CoA Reductase In Mice Induced Hyperlipidemia. Ibn AL-Haitham Journal For Pure and Applied Science, 28(1), 132-141.

Ali, F. W., Kim, J. L., \& Jeon, H. M. (2016). Make it delightful: Customers' experience, satisfaction and loyalty in Malaysian theme parks. Journal of Destination Marketing \& Management, 6, 1-11.

Alnusoor, E. (2014). Contemporary Marketing Applications. Jordan: Alssafaa Publication.

Alubaidi, A. (2016). The Role Ethical Behavior on Pink Marketing. Iraq: Kufa University Press.

Bazilian, E. (2015). Millennial Models Like Gigi Hadid, Fueled by Social, Are Hitting the Fashion Stratosphere. Business Week. And interview with Leonardo Chavez, Maybelline's global brand president, 30 March, 2015. Retreived from https://www.adweek.com/digital/millennial-models-are-hitting-fashion-stratosphere-163745/.

Berletta, M. (2003). Marketing to Women, Understand Reach and Increase Your Share of the World's Largest Market Segment. Michigan: Dearborn Trade Publishing.

Bowen, J.T. \& McCain, S.L. (2015). Transitioning loyalty programs: A commentary on the relationship between customer loyalty and customer satisfaction. International Journal of Contemporary Hospitality Management, 27(3), 415-430. doi: https://doi.org/http://dx.doi.org/10.1108/IJCHM-07-2014-0368.

Casidy, R. \& Wymer, W. (2016). Journal of Retailing and Consumer Services A risk worth taking: Perceived risk as moderator of satisfaction, loyalty, and willingness-to-pay premium price. Journal of Retailing and Consumer Services.32, 189-197. doi: https://doi.org/10.1016/j.jretconser.2016.06.014.

Chang, H.H., Wang, Y.H. \& Yang, W.Y. (2009). The impact of e-service quality, customer satisfaction and loyalty on e-marketing: Moderating effect of perceived value. Total Quality Management \& Business Excellence. 20(4), 423-443. doi: https://doi.org/10.1080/14783360902781923. 
Chen, M.F. \& Wang, L.H. (2009). The Moderating Role of Switching barriers on Customer loyalty in the life insurance industry. The Service Industries Journal. 29(1), 213-221.

Dick, A.S., \& Basu, K. (1994). Customer Loyalty: Toward an Integrated Conceptual Framework. Journal of the Academy of Marketing Science. 22(2), 99-113. doi: https://doi.org/10.1177/0092070394222001. doi: https://doi.org/10.1016/j.jdmm.2016.05.003.

Dwivedi, A. \& Merrilees, B. (2016). Holistic consumer evaluation of retail corporate brands and impact on consumer loyalty intentions. Australasian Marketing Journal. 24(1), 69-78. Doi: https://doi.org/10.1016/j.ausmj.2016.02.002.

Gazi, A. K. (2019). People With Vulnerabilities To Cyclone In The Coastal Area Of Bangladesh: An Overview. International Journal of Social Sciences and Economic Review, 1(2), 80-91. doi:https://doi.org/10.36923/ijsser.v1i3.43

Hanzaee, K. \& Farsani, F. (2011). The Effects of Brand Image and Perceived Public Relation on Customer Loyalty, World Applied Sciences Journal. 32, 277-286.

Ismail, H. \& Panni, M. (2008). Consumers Perceptions on the Consumerism Issues and Their Influence on Their Purchasing Behavior: A View from Malaysian Food Industry. Journal of Legal, Ethical and Regulatory Issues. 11(1), 43-64.

Istria, M. (2012). Pink Marketing Il marketing al femminile. Milano, Italy: Lupetti Press.

Izogo, E.E. (2016). Antecedents of attitudinal loyalty in a telecom service sector: the Nigerian case. International Journal of Quality \& Reliability Management. 33 (6), 747-768. Doi: https://doi.org/10.1016/j.jretconser.2014.12.010.

Kaddumi, B. (2017). New marketing. Jordan: Hammed for Publishing and Distribution.

Kotler, S. A., Walsh, P., Brender, J. R., \& Ramamoorthy, A. (2014). Differences between amyloid- $\beta$ aggregation in solution and on the membrane: insights into elucidation of the mechanistic details of Alzheimer's disease. Chemical Society Reviews, 43(19), 6692-6700.

Liu, M., Tran, T. M., Abbas Elhaj, A. A., Bøen Torsetnes, S., Jensen, O. N., Sellergren, B., \& Irgum, K. (2017). Molecularly imprinted porous monolithic materials from melamine-formaldehyde for selective trapping of Phosphopeptides. Analytical chemistry, 89(17), 9491-9501.

Massoudi, A. (2020). Consumer Loyalty Indicator as Drivers to Satisfaction. Cihan University-Erbil Journal of Humanities and Social Sciences. 4 (1), 41-45. Doi: https://doi.org/10.24086/cuejhss.vol4n1y2020.pp41-45.

Massoudi, A. H., Jameel, A. S., \& Ahmad, A. R. (2020). Stimulating Organizational Citizenship Behavior by Applying Organizational Commitment and Satisfaction. International Journal of Social Sciences and Economic Review, 2(2), 20-27.

McGoldrick, J. and Freestone, O. (2008). Ethical Product Premiums: Antecedents and Extent of Consumers' Willingness to Pay. International Review of Retail, Distribution and Consumer Research. 18 (2), 185-201.

Pashley, R. (2016). Marketing to Women (The New Rule Book), WARC Exclusive, may2016, p04.

Pourdehghan, A. (2015). The impact of marketing mix elements on brand loyalty: A case study of mobile phone industry. Marketing and Branding Research, 2(1), 44-63.

Rohrer-Vanzo, V., Stern, T., Ponocny-Seliger, E., \& Schwarzbauer, P. (2016). Technical Communication in Assembly Instructions: An Empirical Study to Bridge the Gap Between Theoretical Gender Differences and Their Practical Influence. Journal of Business and Technical Communication. 30(1), 29-58.

Sutter, M., Glätzle-Rützler, D., Balafoutas, L., \& Czermak, S. (2016). Cancelling out early age gender differences in competition: an analysis of policy interventions. Experimental Economics. 19(2), 412-432.

Tanford, S. \& Baloglu, S. (2013). Applying the Loyalty Matrix to Evaluate Casino Loyalty Programs. Cornell Hospitality Quarterly. 54(4), 333-346.

Thaichon, P. and C. Jebarajakirthy, (2016). Evaluating specific service quality aspects which impact on customers' behavioral loyalty in high-tech internet services. Asia Pacific Journal of Marketing and Logistics. 28(1), 141-159.

Woodcock, N. \& Stone, M. \& Foss, B. (2003). The Customer Management Scorecard: Managing CRM for profit. London: Kogan Page.

Yano, C. R. (2013). Pink globalization: Hello Kitty’s trek across the Pacific. Durham, North Carolina: Duke University Press.

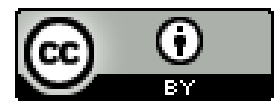

The Vital Role of Pink Marketing in the Creation of Women Loyalty by Aram Hanna Massoud is licensed under a Creative Commons

Attribution 4.0 International License. 